\title{
The Influence of Polyurethane Foam on the Insulation Characteristics of Mortar Pastes
}

\author{
Ahmed Adel Mahmoud ${ }^{1 *}$, Elsayed Abdel Ader Nasr'², Ahmed Abdel Hamed Maamoun' \\ ${ }^{1}$ Department of Physics and Mathematics, Faculty of Engineering, Ain Shams University, Cairo, Egypt \\ ${ }^{2}$ Department of Structural Engineering, Ain Shams University, Cairo, Egypt \\ Email: *Chem4eng@yahoo.com
}

How to cite this paper: Mahmoud, A.A. Nasr, E.A.A. and Maamoun, A.A.H. (2017) The Influence of Polyurethane Foam on the Insulation Characteristics of Mortar Pastes. Journal of Minerals and Materials Characterization and Engineering, 5, 49-61. https://doi.org/10.4236/jmmce.2017.52005

Received: February 10, 2017

Accepted: March 10, 2017

Published: March 13, 2017

Copyright (c) 2017 by authors and Scientific Research Publishing Inc. This work is licensed under the Creative Commons Attribution International License (CC BY 4.0).

http://creativecommons.org/licenses/by/4.0/

\section{Open Access}

\begin{abstract}
Rigid polyurethane foam is found virtually everywhere in our modern world and is used in sound and thermal insulation applications such as refrigerators, insulated buildings, thermosets. Organometallic compounds are used as polyurethane catalysts since they are very highly selective towards the isocyanate-polyol reaction. Also, amine catalysts are used to balance both the gelling reaction and the gas-forming or foaming reaction responsible for foam formation. In this work, the effect of a tin octoate catalyst on the mechanical properties and morphology of polyurethane foam were investigated. Also, the thermal conductivity and sound absorption coefficient for polyurethane foam mortar formulations were measured. The morphological properties of polyurethane foam were investigated using scanning electron microscope to determine the influence of varying the concentration of tin octoate. It was clear from the results that polyurethane foam has good thermal and sound insulation capabilities.
\end{abstract}

\section{Keywords}

Polyurethane Foam, Organometallic Catalyst, Compressive Strength, Thermal Conductivity, Sound Absorption Coefficient

\section{Introduction}

Polyurethane (PU) is actually another name for the family of chemicals known as the urethane polymers, which are composed of two principal raw materials: polyols and polyisocyanates, brought together with catalysts and additives [1].

It is well known that foam is a composite solid-gas material. The continuous phase is the polyurethane polymer and the discontinuous phase is the gas phase. Polyurethanes are an extremely versatile group of polymers, produced in a wide range of crosslink densities, stiffness and densities, from very soft to very hard 
structures [2] [3].

Polyurethane foams are classified according to the nature of the cell structure (open, closed) or according to their stiffness (flexible or rigid). Generally, rigid-type foam materials have been used to increase stiffness and provide extra energy absorption when applied, but their contribution diminishes with aging of the structure.

The molecule weight of the polyols used in polyurethane synthesis ranged between (300 - 10,000 Daltons), in the region of low molecule weight polymers (oligomers), the number of hydroxyl groups/molecule of polyol being generally in the range of (2-8 OH groups/molecule).

A high molecule weight polyol of (2000 - 10,000 Daltons), with a low functionality of around (2 - 3 hydroxyl groups/molecule) leads to an elastic polyurethane and on the contrary, a low molecule weight polyol of (300 - 1000 Daltons), with a high functionality of around (3 - 8 hydroxyl groups/molecule) leads to a rigid cross-linked polyurethane [4].

The most important applications of polyurethane foam are the furniture industry; around $32 \%$ of the total polyurethanes industrial worldwide are used for the production of mattresses from flexible slab stock foams. The second important application for flexible polyurethanes is automotive manufacture (seat cushioning, bumpers, sound insulation and so on). Rigid polyurethane foams are used in thermal insulation of buildings and refrigerators, pipe insulation, thermal insulation in chemical and food industries. The polyurethane elastomers are used for footwear, athletic shoes, pump and pipe linings, industrial tires, microcellular elastomers. Versatile rigid polyurethane foam is even used in solar technology, in horticulture and also for rock consolidation in mining and civil engineering [5] [6].

There are two main reactions important in the manufacture of polyurethane foams as shown in Figure 1. The first one is isocyanate-polyol reaction, identified as the gelling one which forms the backbone urethane group. This reaction leads to the formation of a cross-linked polymer, since polyols with several hydroxyl groups are used. The secondary reaction of a urethane group with an isocyanate group to form an allophanate group is another possible way to further cross-link the polymer.

The second one is isocyanate-water reaction, known as the blowing one which forms the unstable carbamic acid which decomposes to give an amine and carbon dioxide gas in the form of bubbles. Next, the formed amine group reacts with another isocyanate group to give a disubstituted urea. The second part of the blowing reaction contributes to chain extend the aromatic groups of the isocyanate molecules to form linear hard segments. Another secondary reaction involves the formation of biuret and allophanate linkages which could lead to the formation of covalent cross-linking [7] [8] [9].

Catalysts have a key role in polyurethane production being required to maintain a balance between the reaction of the isocyanate and polyol. The combination of very complex Polyurethane chemistry and diverse processing and mold- 


\section{GELLING REACTION}

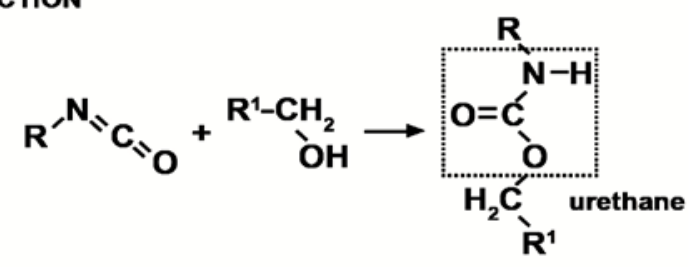

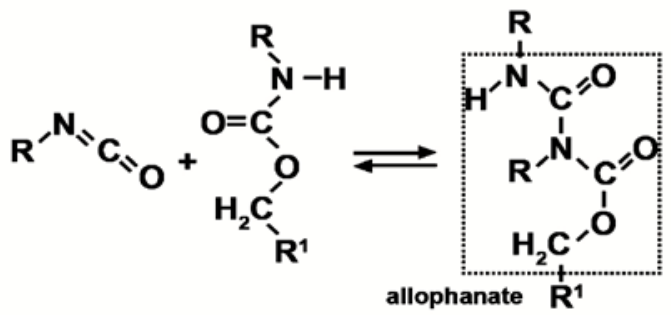

BLOWING REACTION

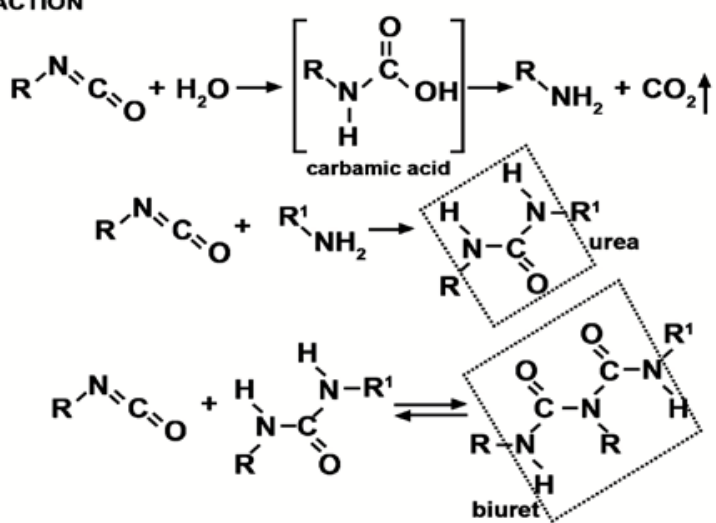

Figure 1. Scheme of gelling and blowing reactions in the preparation of polyurethane foam [7].

ing conditions make great demands of the catalyst. Its main function is to exploit the diverse reactions to create a product with the desired properties. Polyurethane catalysts can be classified into two categories, amine compounds, and organo-metallic complexes. They can then be further classified as to their specificity, balance and relative efficiency [9] [10].

The polymer forming or gelation reaction between the isocyanate and a polyol is promoted by organometallic catalysts. Of the many metals available, tin compounds are the most widely used, these compounds act as lewis acids and are generally thought to function by interacting with basic sites in the isocyanate and polyol compounds as shown in Figure 2 [11].

The preparation of polyurethane foams needs precise kinetic control over the above mentioned competing gelling and blowing reactions [12]. A greater quantity of blowing results in collapsed foams and a greater amount of gelation results in closed-cell structure and shrinkage [13] [14] [15] [16].

\section{Materials}

\subsection{Polyurethane Foam Materials}

The foam formulations were prepared using: 

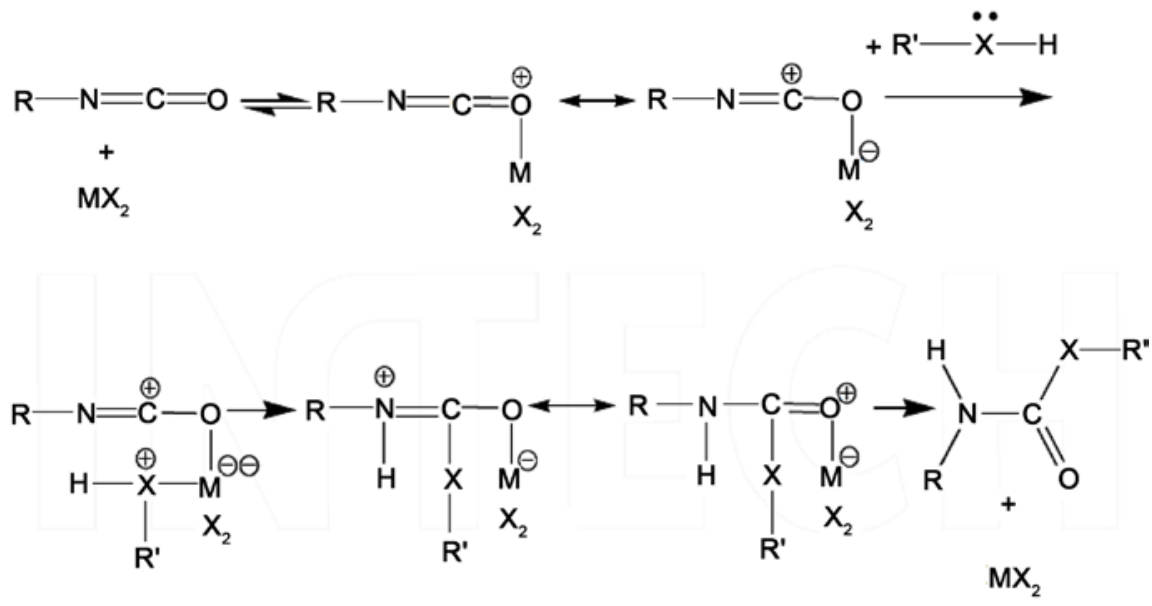

Figure 2. Mechanism of urethane formation (gelling reaction) catalyzed by organometallic compound [12].

VORANOL 3137 having hydroxyl value equal to $56 \mathrm{mg} \mathrm{KOH/g}$, molecular weight of $3000 \mathrm{~g} / \mathrm{mole}$ and viscosity at $25^{\circ} \mathrm{C}$ equal to $235 \mathrm{mpa} \cdot \mathrm{s}$ (Polyether polyol, Dow Chemical), Cosmonate M-200 PMDI (Polymeric methylene diphenyl diisocyanate, Kumho Mitsui Chemicals), Dabco 33-LV catalyst (Triethylenediamine, Air Products Company), Dabco T-9 catalyst (Stannous octoate, Air Products Company), Dabco SI3504 (Silicon surfactant, Air Products Company) and Clean tap water.

\subsection{Polyurethane Foam Mortar Materials}

Polyurethane foam mortar is produced by a combination of Portland cement, sand, potable water and appropriate polyurethane foaming. Properties of the used materials were presented in Table 1.

\subsection{Preparation of Polyurethane Foam}

Rigid polyurethane foam (PUF) was synthesized by two-shot method. At first, polyol mixture, catalysts and surfactant were put into a reactor and mixed for 15 sec using brushless type stirrer at the rotating speed of $2500 \mathrm{rpm}$. After premixing, blowing agent was added to the mixture of reactants and mixed for $10 \mathrm{sec}$ using brushless type stirrer at $3000 \mathrm{rpm}$. Finally PMDI then was added to the reactants and all the reactants were mixed for $7 \mathrm{sec}$ using brushless type stirrer at $5000 \mathrm{rpm}$. Finally, the reactants were poured into the open stainless steel mold $(20 \mathrm{~cm} \times 20 \mathrm{~cm} \times 15 \mathrm{~cm})$ (length $\times$ width $\times$ thickness) as shown in Figure 3 to produce free-rise foams and cured for 1 week at room temperature [17]. In order to avoid the change of thermal conductivity and mechanical strength, the curing was done at room temperature.

\subsection{Preparation of Polyurethane-Mortar Foam}

Polyol, catalysts and surfactant were put into a reactor and mixed for $15 \mathrm{sec}$ using brushless type stirrer at the rotating speed of $2500 \mathrm{rpm}$. After premixing, blowing agent was put into the mixture of reactants and mixed for $10 \mathrm{sec}$ using 


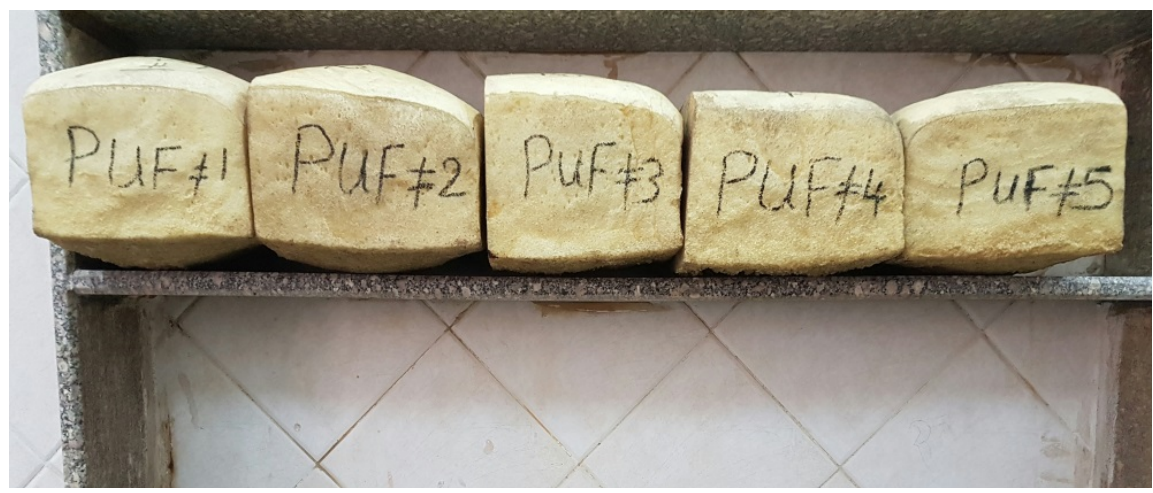

Figure 3. Rigid polyurethane foam samples

Table 1. Properties of used materials.

\begin{tabular}{ccc}
\hline Component & Description & Source \\
\hline Cement & Ordinary Portland cement (CEM I-52.5 N) & Suez Company \\
Sand & Natural sand & \\
& & \\
Polyol (Voranol ${ }^{\mathrm{TM}}$ 3137) & $\begin{array}{c}\text { A 3100 Mw polyetherpolyol with functionality of 3, } \\
87 \% \text { propylene oxide and 13\% ethyleneoxide }\end{array}$ & Dow Chemical \\
Water & Clean tap water & \\
Isocyanate & Polymeric methylene diphenyl diisocyanate & Kumbo Mitsui \\
(PMDI) & Chemicals) \\
Dabco SI3504 & Silicone-polyether copolymer & Air Products \\
Amine catalyst (Dabco $33 \mathrm{LV})$ & 33\% triethylenediamine in 67\% & Air Products \\
TincatalystT-9 & Dipropylene glycol & Air Products \\
\hline
\end{tabular}

brushless type stirrer at 3000, then added to the cement and sand and mixed for $20 \mathrm{sec}$ using brushless type stirrer at the rotating speed of $3000 \mathrm{rpm}$. Finally PMDI was added into the reactants and all the mixes were stirred for $7 \mathrm{sec}$ using brushless type stirrer at $5000 \mathrm{rpm}$. Typical rigid foam mortar formulations were presented in Table 2.

\subsection{Experimental Tests}

\subsubsection{Polyurethane Foam Tests}

\section{1) Compression test}

Compressive strength of the cured polyurethane foam was measured according to American Society for Testing and Materials (ASTM) standard D 1621, "Standard Test Method for Compressive Properties of Rigid Cellular Plastics" by Zwick Roell (Germany) device. Specimens' dimensions of $10 \mathrm{~cm} \times 10 \mathrm{~cm} \times 8 \mathrm{~cm}$ (length, width, thickness) were cut out from the top part of the foam buns. Compressive properties were determined in a $10 \mathrm{kN}$ force range, $30 \%$ displacement till failure and record the reading.

\section{2) Scanning electron microscopy study}

Polyurethane foams were investigated with a scanning electron microscope 
Table 2. Typical rigid foam mortar formulations.

\begin{tabular}{|c|c|c|c|c|c|}
\hline Chemicals* & PUF-1\# & PUF-2\# & PUF-3\# & PUF-4\# & PUF-5\# \\
\hline Cement (Gram) & 250 & 250 & 250 & 250 & 250 \\
\hline Sand (Gram) & 750 & 750 & 750 & 750 & 750 \\
\hline Polyol (Voranol $\left.{ }^{\mathrm{m}} 3137\right)$ & 131.25 & 131.25 & 131.25 & 131.25 & 131.25 \\
\hline Water & 2.6 & 2.6 & 2.6 & 2.6 & 2.6 \\
\hline Isocyanate (COSMONATE M-200) (PMDI) & 157.5 & 157.5 & 157.5 & 157.5 & 157.5 \\
\hline Dabco SI3504 & 2.6 & 2.6 & 2.6 & 2.6 & 2.6 \\
\hline Amine catalyst (Dabco $33 \mathrm{LV})$ & 2.6 & 2.6 & 2.6 & 2.6 & 2.3 \\
\hline Tin catalyst (DabcoT-9) & 0.60 & 0.80 & 1 & 1.2 & 1.4 \\
\hline
\end{tabular}

${ }^{*}$ part per weight (p.p.wt).

(SEM) FEI Inspect S, Czech Republic. The specimens were mounted on an aluminum stub and sputter coated with a thin layer of gold to avoid electrostatic charging during examination. The accelerating voltage was $30 \mathrm{kV}$ and magnification was 70 .

\section{3) Tensile strength}

The tensile strength of a substance is the maximum amount of tensile stress that it can take before failure. The tensile strength of the cured polyurethane foams was measured according to American Society for Testing and Materials (ASTM) standard D 1623, "Standard Test Method for Tensile and Tensile Adhesion Properties of Rigid Cellular Plastics" by Zwick Roell (Germany) device with Load cell is $100 \mathrm{~N}$. At the end of the curing process and after de molding, the edges of the specimens are cut using a sharp knife. The resultant samples used for tensile testing are with dumbbell shape geometry.

\subsubsection{Polyurethane Foam-Mortar Tests}

\section{1) Sound absorption measurements}

The measurement and calculation procedures for the determination of the normal incidence sound absorption coefficient and related acoustic properties of a sample was carried out using a two-microphone impedance tube (Type 4206). It is based on ISO 10534-2 and ASTM E1050 and includes transfer function calibration to eliminate the effects of phase and amplitude mismatches between the two measurement channels. The large sample tube has an inner diameter of 100 $\mathrm{mm}$. It is rated for a frequency range of 100 to $1600 \mathrm{~Hz}$.

\section{2) Thermal conductivity}

Thermal conductivity was measured using thermal conductivity analyzer (model TCA Point2), Anacon. A sample was placed in the test section between two plates which are maintained at different temperatures during the test. Dimensions of the specimen were $30 \mathrm{~cm} \times 30 \mathrm{~cm} \times 3 \mathrm{~cm}$ (width $\times$ length $\times$ thickness). The thermal conductivity of samples was measured according to ASTM C518. The test was carried out for selected mixes PUF\#1, PUF\#3 and PUF\#5. 


\section{Results and Discussion}

Polyurethane foams are formed by the reaction of polyol, polyisocyanate and water in the presence of catalysts and other auxiliary agents. Catalysts play a vital role not only in the regulation and balance between the gelling and blowing reactions, but also in the optimization of the foam properties and the curing speed during the foam synthesis. Tertiary amines in combination with tin octoate are most widely used catalysts in the manufacture of polyurethane foams [18] [19].

\subsection{Compression Strength}

Analysis of data in Table 3 show that by increasing the percentages of tin catalyst leads to increase in compressive strength of polyurethane foam as shown in Figure 4; this is due to that tin catalyst enhances gelling reaction between polyether polyol and polyisocyanate which give rise to rigid polyurethane foam with acceptable compressive strength.

\subsection{Effect of Tin Catalyst on Cell Morphology}

Also increasing amount of tin catalyst in polyurethane mixes enhanced gelling reaction at the expense of blowing reaction which leads to more compact cell structure of polyurethane foam. This refers to high cross linking polymer inside samples with excellent mechanical properties.

\subsection{Tensile Strength}

From the results in Table 4 it can be concluded that increasing in the amount of tin catalyst, lead to more compact cell structure according to scanning electron

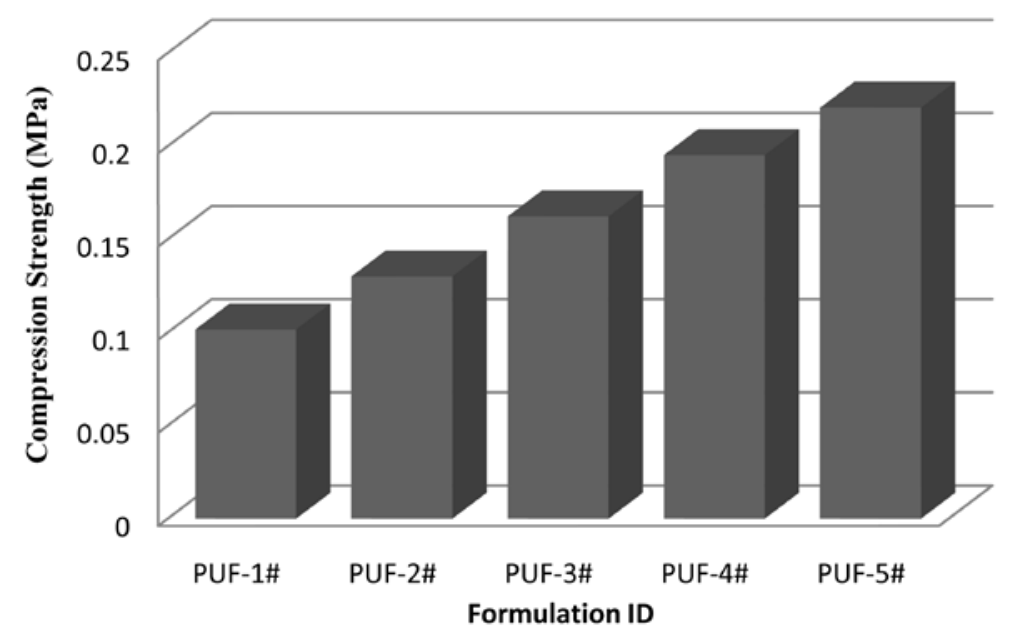

Figure 4. Relation between different percentages of tin catalyst and compressive strength of polyurethane foam.

Table 3. Compressive strength results of polyurethane foam.

\begin{tabular}{cccccc}
\hline Sample & PUF-1\# & PUF-2\# & PUF-3\# & PUF-4\# & PUF-5\# \\
\hline Compression strength (MPa) & 0.10161 & 0.1301 & 0.1623 & 0.1952 & 0.2206 \\
\hline
\end{tabular}


Table 4. Tensile strength of polyurethane foam.

\begin{tabular}{cccccc}
\hline Sample & PUF-1\# & PUF-2\# & PUF-3\# & PUF-4\# & PUF-5\# \\
\hline Tensile strength (MPa) & 0.12 & 0.14 & 0.16 & 0.22 & 0.17 \\
\hline
\end{tabular}

microscope as shown in Figure 5 (PUF-1\# (A), PUF-2\# (B), PUF-3\# (C), PUF-4\# (D) and PUF-5(E)) which cause increase in the tensile strength values until reach to optimum ratio (Maximum tensile strength) at PUF\#4 according to Figure 6.

\subsection{Sound Absorption of Polyurethane Mortar Mixes}

It is clear from the results that the polyurethane foam material has high sound absorption for sound waves in low frequencies range $100 \mathrm{~Hz}$ to $1600 \mathrm{~Hz}$ as shown in Figure 7.

Analysis of the data in Table 5 shows that Increasing tin catalyst from (PUF\# 1 to PUF\#3) lead to increasing in sound absorption coefficient, this is can be interpreted by high porosity inside the cellular structure of the samples in these range. But from (PUF\#3 to PUF\#5) gelling increase and hence porosity decreases which leads to lowering of sound absorption coefficient as shown in Figure 8.

\subsection{Thermal Conductivity for Polyurethane Mortar Mixes}

Analysis of data in Table 6 indicates that foam has low thermal conductivity comparing with limestone, concrete, sand and rubber. This could be due to cellular structure of foam material as shown in Figure 9. It is clear from the results in Table 7 that the thermal conductivity is very low for polymeric foam comparing with sample containing no polymer (Blank) as shown in Figure 10 because polyurethane foam consists of $92 \%$ to $98 \%$ of closed cells which are filled with insulating gases. Only $8 \%$ to $2 \%$ of the foam is solid polyurethane polymer [20]. The percentage of solid polymer is determined by the density of the foam: the lower the density of the foam, the lower the percentage of solid polymer. The closed cells are filled with several gases released by blowing agents during the manufacture of the polyurethane foam.

\section{Conclusions}

The following conclusions could be drawn from this study:

Of the many organometallic compounds available, tin octoate compounds are the most widely used, to promote polyol-isocyanate reaction which leads to acceptable mechanical strength for polyurethane foam.

Thermal conductivity measurement indicates that rigid polyurethane foam insulation materials display excellent insulation characteristics. They have extremely low thermal conductivity values and can achieve optimal energy savings.

The excellent mechanical strength values and exceptional durability of rigid polyurethane foam fulfill all the requirements made of insulating materials used in the building industry. 

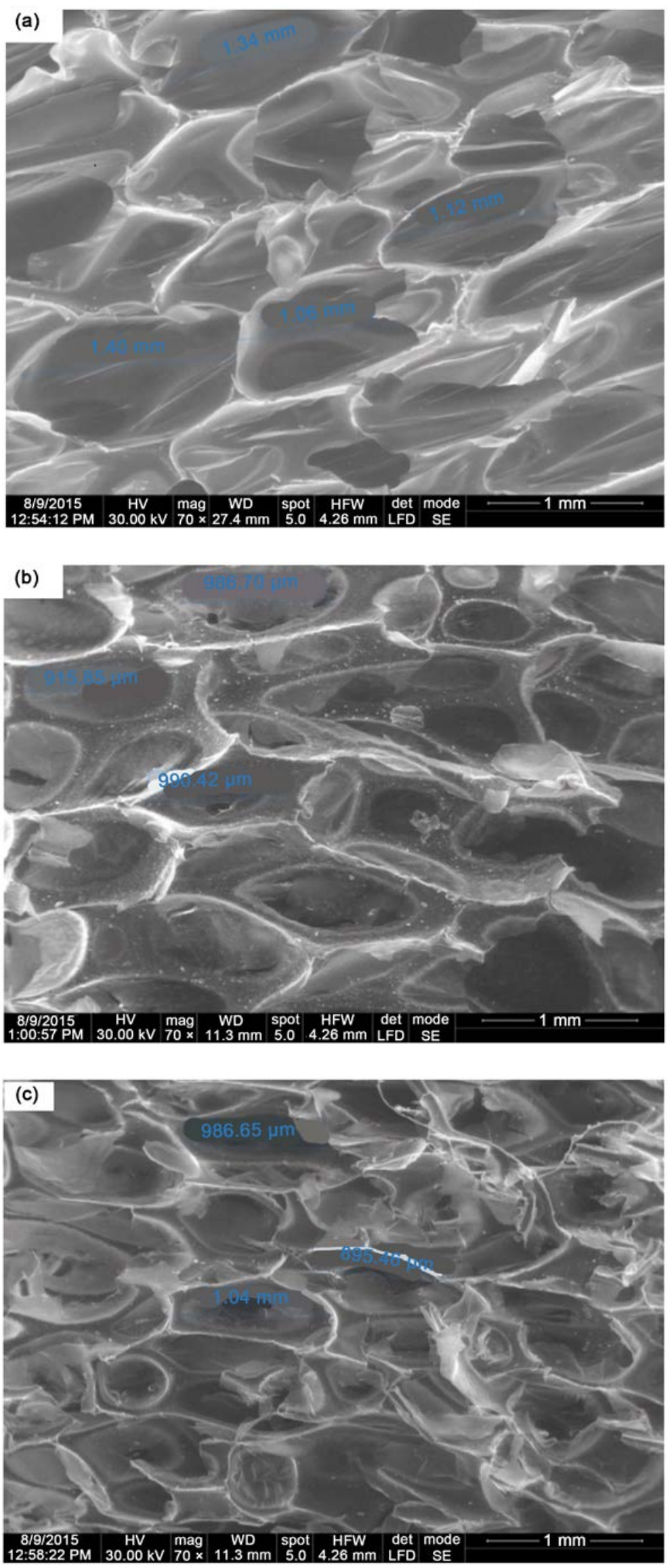


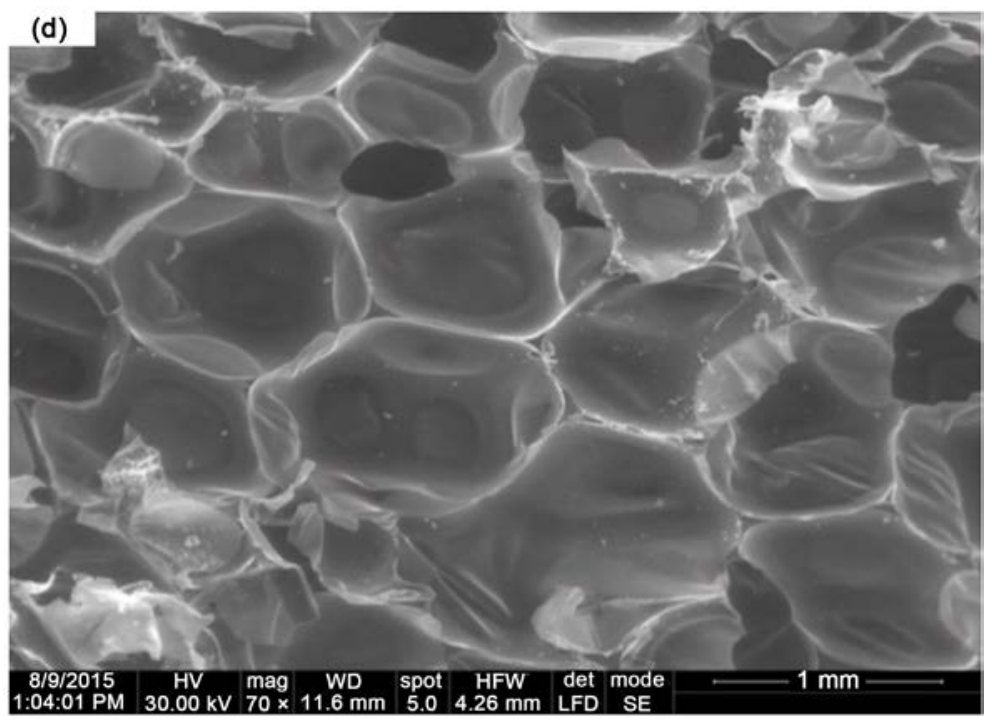

(e)

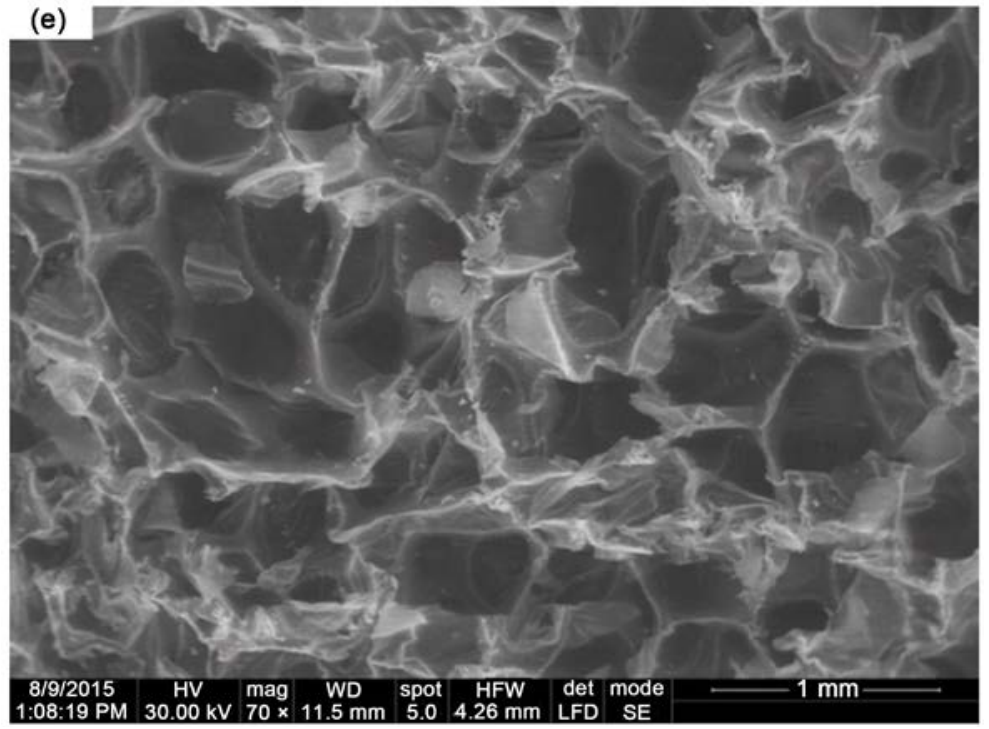

Figure 5. SEM micrographs for PUF-1\# (a), PUF-2\# (b), PUF-3\# (c), PUF-4\# (d) and PUF-5 (e) showing the effect of increasing tin catalyst on the cellular structure of polyurethane foam.

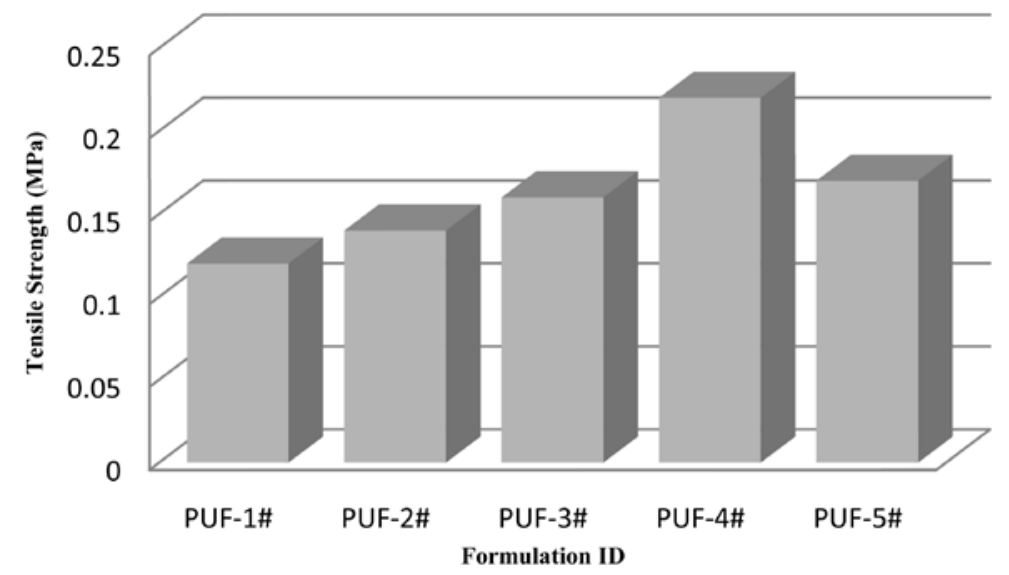

Figure 6. Relation between different percentages of tin catalyst and tensile strength. 


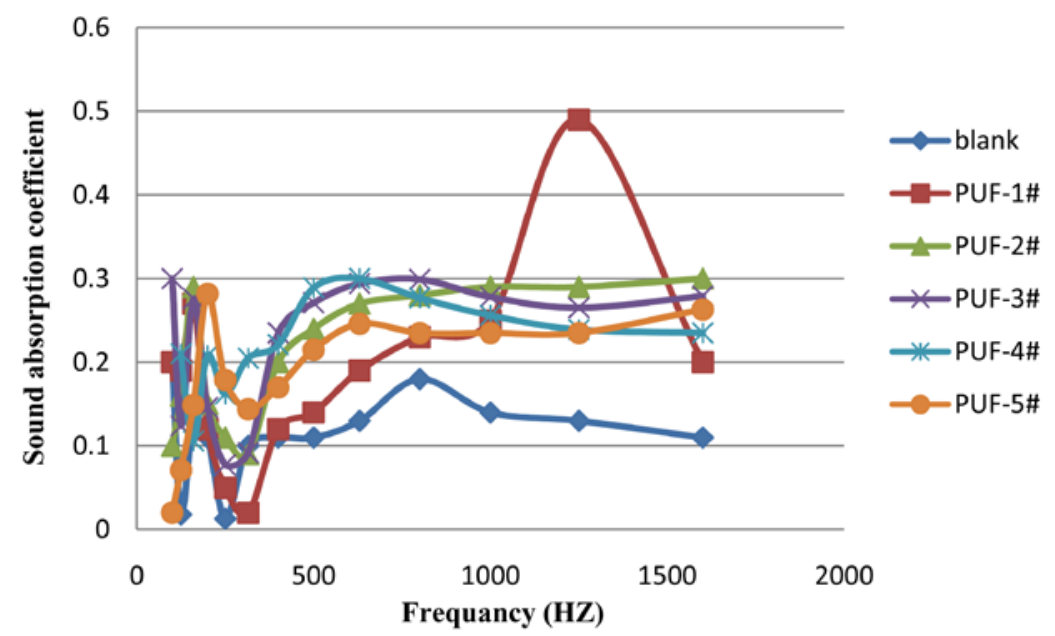

Figure 7. Sound absorption coefficient vs. frequency of the different samples of polyurethane foam containing various dosages of tin catalyst.

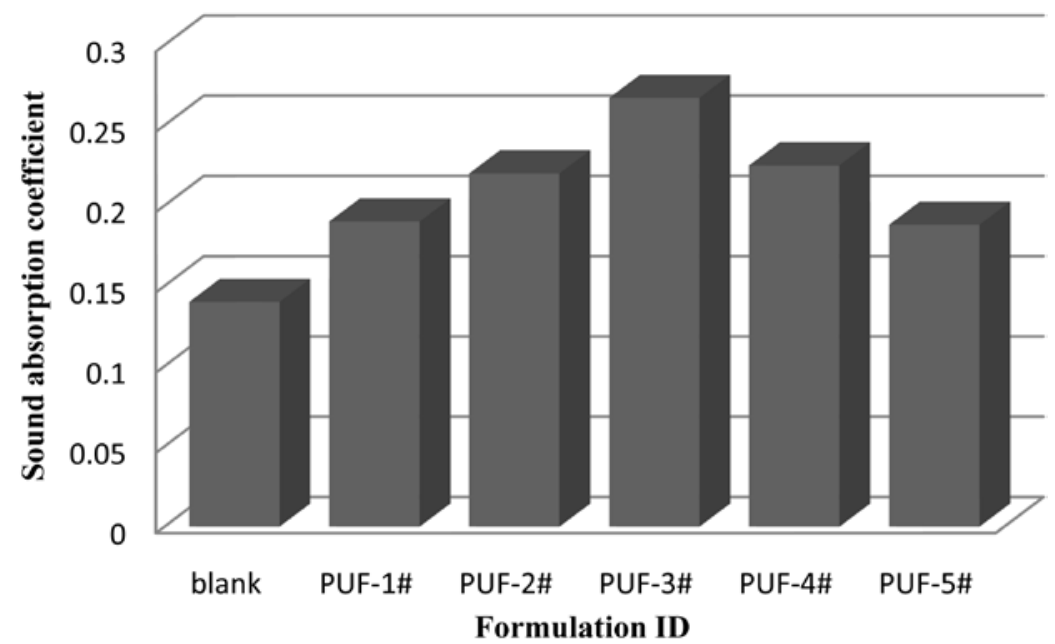

Figure 8. Relation between sound absorption coefficient and different formulations from polyurethane foam contains dissimilar dosages from tin catalyst.

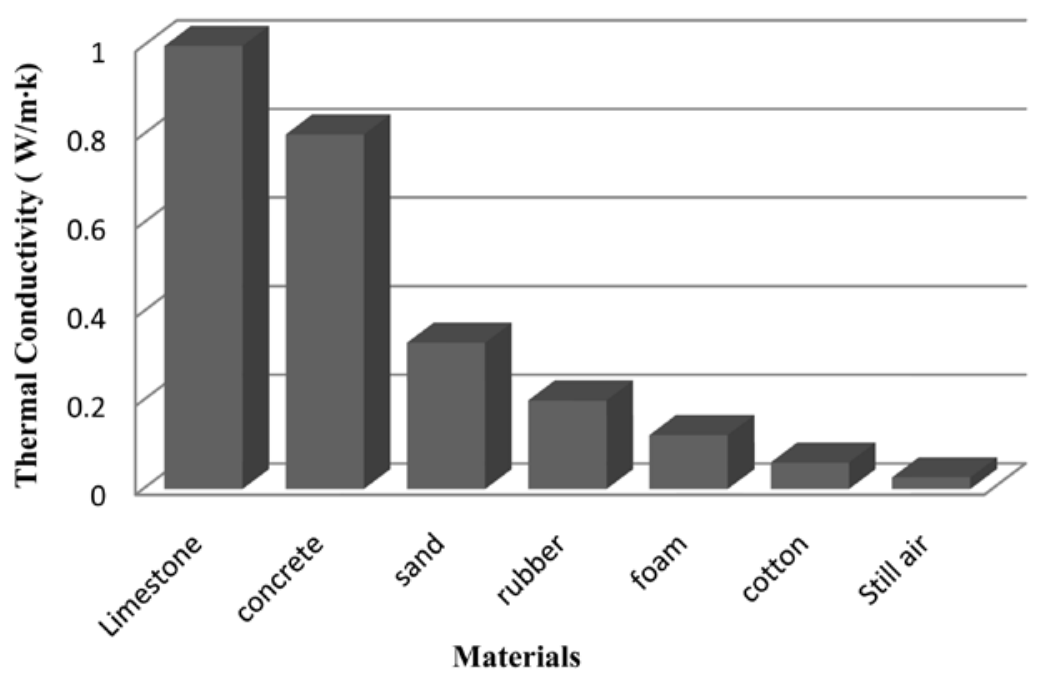

Figure 9. Comparison between thermal conductivities of different materials. 


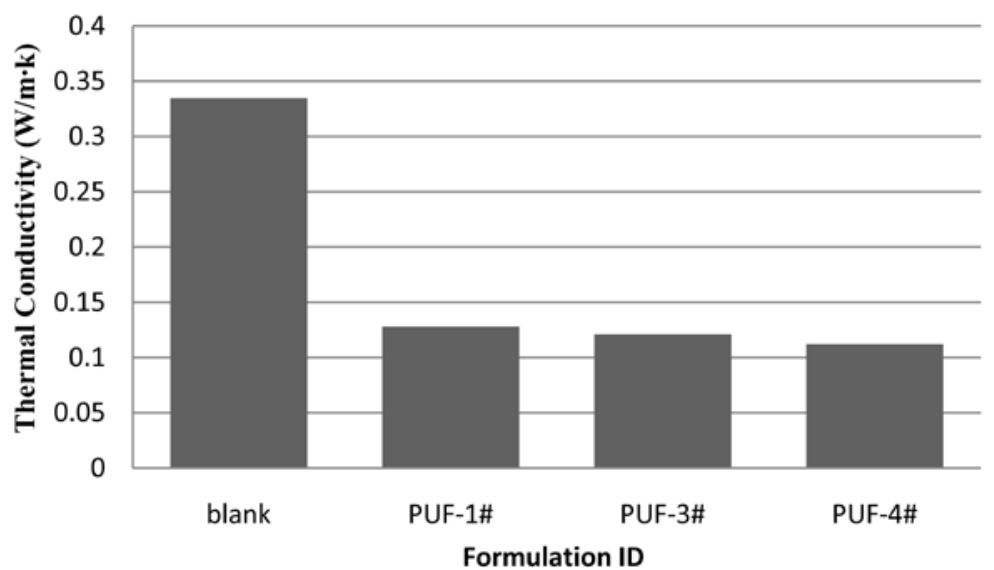

Figure 10. Relation between thermal conductivity and different formulations from polyurethane foam contains dissimilar dosages from tin catalyst.

Table 5. Sound absorption coefficient for polyurethane mortar mixes.

\begin{tabular}{ccccccc}
\hline Sample & Blank & PUF-1\# & PUF-2\# & PUF-3\# & PUF-4\# & PUF-5\# \\
\hline Sound absorption coefficient & 0.14 & 0.19 & 0.22 & 0.267 & 0.225 & 0.188 \\
\hline
\end{tabular}

Table 6. Thermal conductivity values for different materials [17].

\begin{tabular}{cccccccc}
\hline Materials & Limestone & Concrete & Sand & Rubber & Foam & Cotton & Still air \\
\hline Thermal conductivity $(\mathrm{W} / \mathrm{m} \cdot \mathrm{k})$ & 1 & 0.8 & 0.33 & 0.2 & 0.122 & 0.06 & 0.0262 \\
\hline
\end{tabular}

Table 7. Thermal conductivity for selected samples of polyurethane mortar mixes.

\begin{tabular}{ccccc}
\hline Sample & Blank & PUF-1\# & PUF-3\# & PUF-4\# \\
\hline Thermal conductivity $(\mathrm{W} / \mathrm{m} \cdot \mathrm{K})$ & 0.335 & 0.128 & 0.121 & 0.112 \\
\hline
\end{tabular}

Polyurethane foam has good acoustic characteristics due to large amount of pores inside the cellular structure of rigid polyurethane foam.

\section{References}

[1] Chorkendorff, I. and Niemantsverdriet, J.W. (2003) Concepts of Modern Catalysis and Kinetics, WILEY-VCH Verlag GmbH \& Co. KGaA, Weinheim.

[2] Lutz, P.J., Rempp, P. and Merrill, E.W. (2004) Polymer Synthesis. 3rd Edition, Wiley-VCH, New York.

[3] Randall, D. and Lee, S. (2002) The Polyurethanes Book, Wiley Ltd., New York.

[4] Szycher, M. (2012) Handbook of Polyurethanes. 2nd Edition, CRC Press, Boca Raton.

[5] Maris, R.V., Tamano, Y., Yoshimura, H. and Gay, K.M. (2005) Polyurethane Catalysis by Tertiary Amines. Journal of Cellular Plastics, 41, 305-322.

https://doi.org/10.1177/0021955X05055113

[6] Delebecq, E., Pascault, J.-P., Boutevin, B. and Ganachaud, F. (2013) On the Versatility of Urethane/Urea Bonds: Reversibility, Blocked Isocyanate, and Non-Isocyanate Urethane. Chemical Reviews, 113, 80-118. https://doi.org/10.1021/cr300195n

[7] Dworakowska, S., Bogdał, D., Zaccheria, F. and Ravasio, N. (2014) The Role of Ca- 
talysis in the Synthesis of Polyurethane Foams Based on Renewable Raw Materials. Catalysis Today, 233, 148-156. https://doi.org/10.1016/j.cattod.2013.11.054

[8] Lee, S.T. and Ramesh, N.S. (2004) Polymeric Foams, Mechanisms and Materials, Technology and Engineering. Polymeric Foam Series, CRC, Boca Raton.

[9] Ionescu, M. (2005) Chemistry and Technology of Polyols for Polyurethanes. Rapra Technology Limited, Shawbury.

[10] Mallavadhani, U.V. and Fleury-Bregeot, N. (2010) 1,4-Diazabicyclo[2.2.2] octane, in Encyclopedia of Reagents for Organic Synthesis. John Wiley \& Sons, Ltd., Hoboken.

[11] Silva, L. and Bordado, J.C. (2004) Recent Developments in Polyurethane Catalysis, Catalytic Mechanisms Review. Catalysis Reviews, 46, 31-51. https://doi.org/10.1081/CR-120027049

[12] Brandl, C., Grimminger, J. and Paul, J. (2015) Advances in Additives for Poly-Isocyanurate Foams. Air Products and Chemicals Inc., Hamilton.

[13] Bogdan, M., Hoerter, J. and Moore Jr, F.O. (2005) Meeting the Insulation Requirements of the Building Envelope with Polyurethane and Polyisocyanurate Foam. Journal of Cellular Plastics, 41, 41-56.

[14] Chattopadhyay, D.K. and Webster, D.C. (2009) Thermal Stability and flame Retardancy of Polyurethanes. Progress in Polymer Science, 34, 1068-1133. https://doi.org/10.1016/j.progpolymsci.2009.06.002

[15] Kim, S.H., Lee, M.C., Kim, H.D., Park, H.C., Jeong, H.M., Yoon, K.S. and Kim, B.K. (2001) Nanoclay Reinforced Rigid Polyurethane Foams. Journal of Applied Polymer Science, 117, 1593-1605.

[16] Rajput, S.D., Mahulikar, P.P. and Gite, V.V. (2014) Biobased Dimer Fatty Acid Containing Two Pack Polyurethane for Wood Finished Coatings. Progress in Organic Coatings, 77, 38-46. https://doi.org/10.1016/j.porgcoat.2013.07.020

[17] Gandini, A. (2008) Polymers from Renewable Resources: A Challenge for the Future of Macromolecular Materials. Macromolecules, 41, 9491-9504. https://doi.org/10.1021/ma801735u

[18] Levchik, S., Luda, M.P., Bracco, P., Nada, P. and Costa, L. (2005) Discoloration in Fire-Retardant Flexible Polyurethane Foams. Journal of Cellular Plastics, 41, 235 250.

[19] Zhang, L.Q., Zhang, M., Zhou, Y.H. and Hu, L.H. (2013) The Study of Mechanical Behavior and Flame Retardancy of Castor Oil Phosphate-Based Rigid Polyurethane Foam Composites Containing Expanded Graphite and Triethyl Phosphate. Polymer Degradation and Stability, 98, 2784-2794. https://doi.org/10.1016/j.polymdegradstab.2013.10.015

[20] Seo, W.J., Jung, H.C., Kim. W.N., Lee, Y.B., Choo, K.H. and Kim, S.B. (2003) Mechanical, Morphological, and Thermal Properties of Rigid Polyurethane Foams Blown by Distilled Water. Journal of Applied Polymer Science, 90, 12-21. https://doi.org/10.1002/app.12238 
Submit or recommend next manuscript to SCIRP and we will provide best service for you:

Accepting pre-submission inquiries through Email, Facebook, LinkedIn, Twitter, etc. A wide selection of journals (inclusive of 9 subjects, more than 200 journals)

Providing 24-hour high-quality service

User-friendly online submission system

Fair and swift peer-review system

Efficient typesetting and proofreading procedure

Display of the result of downloads and visits, as well as the number of cited articles Maximum dissemination of your research work

Submit your manuscript at: http://papersubmission.scirp.org/

Or contact jmmce@scirp.org 